\section{MODELING WALKING BEHAVIOR IN CITIES BASED ON STREET NETWORK AND LAND-USE CHARACTERISTICS: THE CASE OF ISTANBUL} Ayşe ÖZBİL*
Received: 04.07.2012; Final Text: 03.12.2012

Keywords: Street connectivity; pedestrian movement; urban street network; land-use; İstanbul.

\section{INTRODUCTION}

The aim of many recent planning investments is to reduce automobile dependence and induce non-auto commuting by implementing various urban design principles along with the ideals of New Urbanism and smart growth in re-shaping the urban form. To date, studies of the built environment's impact on individual travel behaviour have generally focused on population densities, land-use mix and the qualities of urban design. The latter has often been treated with reference to the immediate condition of individual streets, ranging from the dimensions and design of sidewalks to the prevailing levels of environmental comfort that may encourage pedestrian movement (Gehl et al., 2006).

However; equal attention must be paid to the structure of street networks and street connectivity to understand and design urban environments, where pedestrian movement is distributed over larger areas, with multiple and overlapping pedestrian paths and varied intensities. In this research the emphasis is on the structure of connectivity. The study on spatial structure of street layout is aimed to address a recurrent critical issue within on-going research on walking behaviour. That is the development of adequate objective methods for assessing the impact of physical environment on walking. So far, most models estimated to probe this relationship have been incompletely specified due to the difficulty of balancing the over-reliance on perceptions of the physical environment with a corresponding objective set of measures (Moudon et al., 2006). This is partly because of the scale of models currently in use. Most research designs dealing with studies of pedestrian movement employ a range of environmental variables concerned with the local qualities of the environment. However, these factors are actually associated with the character or quality of an entire area -a neighbourhood, a district, or a city. Moreover, it is very difficult to build these factors back into recommendations for designs aimed to create walking-friendly 
environments. This research builds on the premise that structural aspects of physical environment -in addition to such local, perceptual factors- also need to be considered as offering a significant, even over-riding, influence on walking behaviour.

This study investigates the significance of street network design in affecting the distribution of pedestrian movement by adopting appropriate measures of street connectivity which are sensitive to both the density and spatial structure of street networks. Three 1 mile $x 1$ mile areas in İstanbul are studied to test the presence, strength, and nature of the relationship between street configuration, land-use patterns and densities of pedestrian movement. The scope of this study is two-fold: first, it intends to identify underlying regularities that link pedestrian flows to new measures of street connectivity, which have the potential to contribute to an understanding of movement at a finer grain and raise new questions. Second, this paper discusses how the rates of pedestrian movement are affected by landuse compositions at the street level. In the longer term this might lead to models which can account not only for the relative spatial distribution of movement within an area according to configuration of street network, but also for the magnitude of movement according to land-use. By better understanding the effect of street connectivity and land-use on pedestrian movement, we can better integrate the knowledge base that informs not only planning but also architectural design. This link becomes even more important if we are to develop more sustainable cities.

\section{CONCEPTUAL FRAMEWORK}

Empirical research on how urban form factors can influence pedestrian travel has framed around density, land-use and design of street network. There is substantial amount of literature that has acknowledged density as a significant predictor of travel choice. A plethora of recent studies have suggested that compact developments with higher [population/ employment/development] densities degenerate vehicle trips and encourage non-motorized travel by reducing the distance between origins and destinations; offering a wider variety of choices for commuting and a better quality of transit services; and by triggering changes in the overall travel pattern of households (Krizek, 2003; Holtzclaw, 1994; Ewing et al., 1994). While some researchers have proved population and employment density to have the greatest impacts on household travel patterns and mode choice (Pushkarev and Zupan, 1977; Newman and Kenworthy, 1989; Cervero, 1988), others have argued that benefits of density are in fact dependent on accessibility to regional activities and job-housing balance, which significantly reduces vehicular travel (Guiliano, 1991; Cervero, 1989).

Explanations regarding the measurable impact of land-use characteristics on pedestrian travel and how dense land-use patterns play a significant role in encouraging walks follow similar logics. High density levels of mix-use and presence of retail activities near residences increase nonwork trips and induce non-auto commuting (Cervero, 1996; Krizek, 2003). More importantly, increased levels of land-use mix at the trip origins and destinations yield in increase in walking (Frank and Pivo, 1994; Cervero, 1988). The general inference that can be drawn from these studies is that urban environments with pedestrian-oriented land-use compositions are more congenial to walking. 
To date, studies of the local environment's impact on individual travel have focused on densities and land-use mixes, yet there has been relatively little explicit research on the role of street layout. Various quantitative measures have been suggested by the urban-design literature to evaluate pedestrian accessibility and measure street connectivity. The distance between origins and destinations for walking and the total length of streets covering an area have been employed by some authors (Handy, 1996; Aultman-Hall et al., 1997) to describe how the character of streets differs at neighborhood and regional levels. Some researchers have chosen to calculate the density and pattern of intersections, average block areas and block face lengths per unit area to capture the degree of network connectivity (Southworth and Owens, 1993; Cervero and Kockelman, 1997; Siksna, 1997). Apart from these average measures of street density, some studies have analyzed the underlying differences of street types, such as comparative typological schemes discriminating between rectilinear and curvilinear layouts (Crane and Crepeau, 1998; Ewing and Cervero, 2001) or the distinctions between traditional and suburban planned units (Ewing et al., 1994; Handy et al., 2005; Rodriguez et al., 2006), to reveal the link between street network and pedestrian behavior. In addition, more discriminating measures, such as pedestrian route directness, which is the ratio of network distance to straight line distance (Hess, 1997; Lee and Moudon, 2006; Randall and Baetz, 2001; Handy et al., 2003), and pedestrian catchment areas capturing all destinations accessible within a walking distance from a specific point (Hess, 1997; Hess et al., 1999) are used to describe structural differences in street networks. A common theme of this body of research is that inordinate size of street blocks or the lack of a fine-grained urban network of densely interconnected streets fails to promote greater transit mode shares, higher proportion of walking, and more walk trips.

Yet, in spite of the burgeoning literature concerned with street connectivity, the effect of street network configuration on overall travel remains unclear. One reason is the absence of commonly accepted measures that capture the internal structure of urban areas. The significance of spatial structure in affecting pedestrian movement has been addressed through the framework of configurational analysis of space syntax. The phrase "configurational analysis" refers to any kind of spatial analysis which characterizes the relation of each elementary spatial unit, here the road segment, to all others. The underlying theory of space syntax is that the layout of street network serves as the primary determinant of movement patterns throughout the urban grid, over and above other determinants (Hillier et al., 1993; Hillier et al., 1984; Peponis, 1989; Peponis et. al., 1997; Penn et al., 1998). Whereas communities of urban design and planning literature accept land-use as an independent variable, space syntax claims that land-uses which are movement dependent tend to be located along locations with high-movement potentials determined by the urban structure itself (Hillier et al., 1983; Hillier, 1996; Hillier, 1999a; Hillier, 1999b), thus considering land-use as a dependent variable in urban studies. Given the fact that the structure of streets remains fixed over longer periods of time as compared to particular buildings or land-uses, the effect of urban configuration is claimed to be primary. The reason that the distribution of land-use can reinforce urban configuration is because land-use becomes tuned to spatial structure, as cities evolve over time. In the case of space syntax, particular attention is given to the number of direction changes that are necessary to move from one location to another. The underlying theory is developed from a number of studies of urban environments which show that road 
Figure 1. Definition of axial map, line segments and road segments segments that are accessible from their surroundings with fewer direction changes tend to attract higher flows (Hillier et al. 1987; Peponis, 1989). Direction changes are associated with cognitive effort (Bailenson et al., 2000; Crowe et al., 2000; Sadalla and Magel, 1980). Thus, it seems intuitively plausible that pedestrian movement is drawn to those streets that act as a primary reference system, providing pedestrians with cues that let them locate themselves within the global environment, hence, allowing for exploration without the fear of getting lost. From the point of view of this study, the key implication of previous syntactic studies is that our understanding of how street networks impact behaviors and performances of different kinds is significantly improved when we apply stronger descriptive methods and better measures of spatial properties.

\section{STRUCTURE OF THE STUDY}

This study focuses on measures of connectivity and land-use as the means to generate movement patterns. Measures used to evaluate the connectivity of street network are explained further in the paper. Land-use data include the gross densities of residential and non-residential land-use compositions at street level. Overall three grains of data are employed in this analysis: measures of street connectivity; land-use patterns; and pedestrian volumes.

\section{Measures of Street Connectivity}

The relationship between the distribution of pedestrian movement and the spatial structure of street layouts is well established (Peponis et al., 1996; Peponis et al., 1989; Hillier et al., 1993; Hillier and Iida, 2005). The most cited pioneering studies have relied on "axial maps" of street networks drawn by the researchers. In this research new measures of street connectivity that have been developed to allow for the analysis of standard GIS-based representations of street networks according to street center-lines are applied (Peponis et al., 2008). The unit of analysis is the road segment. Road segments extend between choice nodes, or street intersections at which movement can proceed in two or more alternative directions. Figure 1 illustrates the new unit of analysis by clarifying the difference between axial maps, line segments and road segments.

Analysis is based on finding the subset of street center-lines and parts of lines that can be reached subject to some limitation. When the limitation is metric distance, the total length of streets reached is called Metric Reach. Metric reach captures the density of streets and street connections accessible from each individual road segment. This is measured by the total street length accessible from each road segment moving in all possible

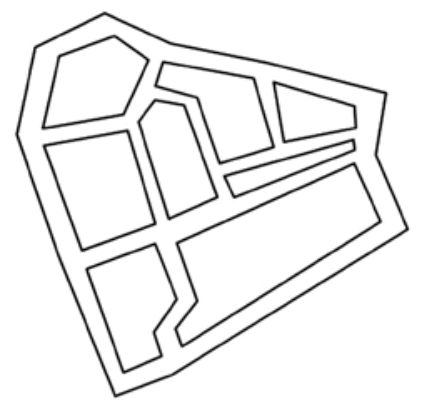

a. figurative urban system

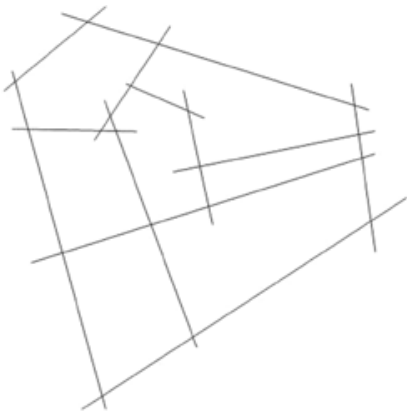

b.

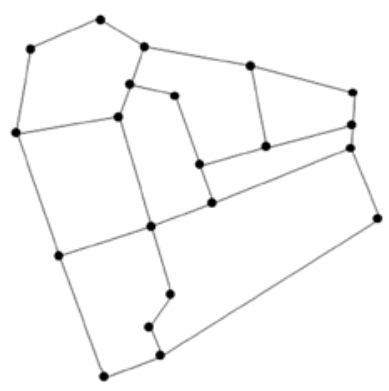

c.

axial map of urban network

individual line segments

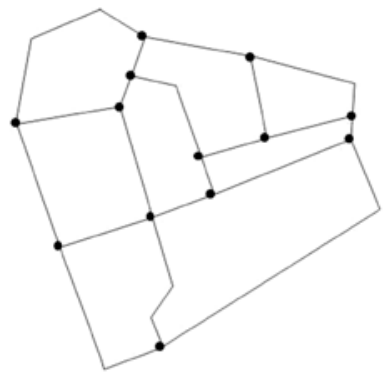

d. individual road segments 
directions up to a parametrically specified metric distance threshold. When the limitation is a number of permissible direction changes, the total length of streets reached is called Directional Reach. Directional reach measures the extent to which the entire street network is accessible with few direction changes. This is measured by the street length which is accessible from each road segment without changing more than a parametrically specified number of directions. While metric reach extends uniformly along the streets surrounding a given road segment, directional reach may extend much less uniformly, because it is sensitive to the shape and alignment of streets, not merely to their density. The connectivity measures used in this paper are inherently parametric, in that one can vary what rotation angle counts as a direction change or what walking threshold is used to measure the catchment area associated with each individual road segment. The inclusion of directional reach in the analysis is a direct response to the research findings suggesting that the distribution of pedestrian movement may have cognitive dimensions associated with it. The measures of metric and directional reach not only help compare one area with another, on average, but they also help discriminate between proximate road segments within the same area, capturing the spatial structure of the urban network. In this study metric and directional reach were computed for 1 mile distance threshold and for two direction changes subject to a $10^{\circ}$ angle threshold respectively. Computing directional reach for two direction changes provides an estimate of how well a road segment is embedded in its surroundings from the point of view of directional distance. $10^{\circ}$ is selected as the parametric threshold to make the analysis more sensitive to the distinction between linear and curvilinear systems. The choice, however, is also consistent with literature suggesting that turns that vary minimally (between $10^{\circ}$ and $15^{\circ}$ ) from an axis orthogonal to the direction of travel are the least disorienting (Montello, 1991; Sadalla and Montello, 1989).

\section{Measures of Land-use Compositions}

Parcel-based data were categorized into residential (single and multifamily) and non-residential (office, retail, institution, recreation, industrial) for the purpose of distinguishing between the effects of each on the distribution of movement. Gross densities of land-use were calculated as a linear measure at the road segment scale by computing residential and non-residential building square meter associated with each individual segment, and relativized by segment length: square meter of development per $100 \mathrm{~m}$ of street length. Figure 2 demonstrates the way in which development densities were associated with individual road segments.

Figure 2. Gross densities of buildings that open onto the individual road segment were calculated for each segment covered in each route.
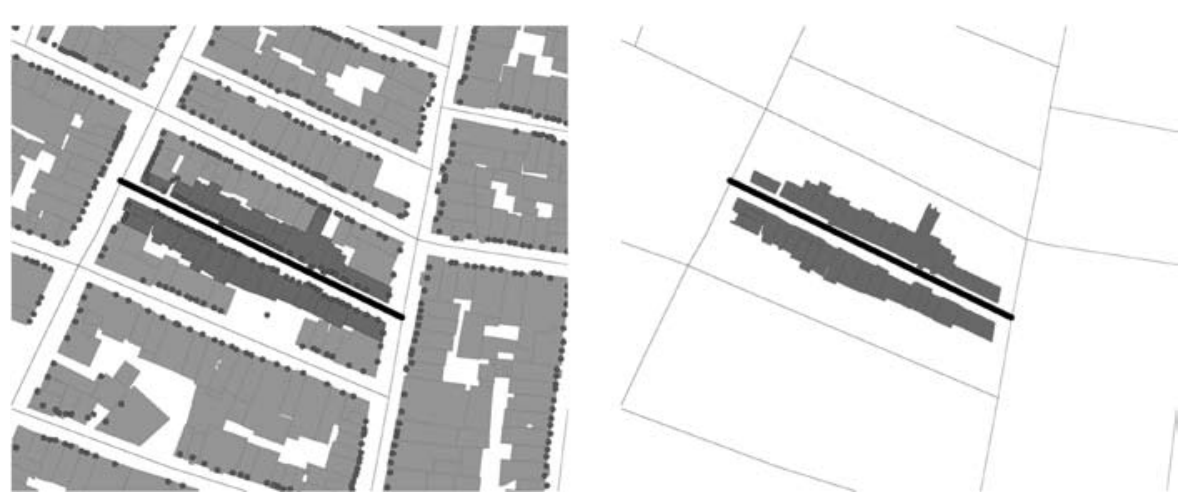


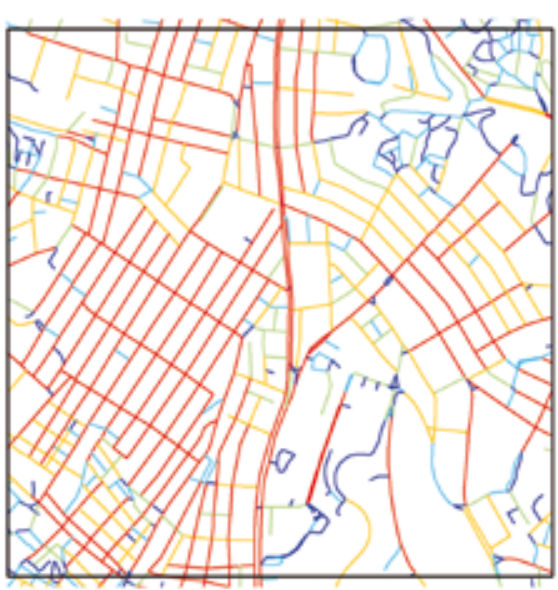

a. Nişantaşı

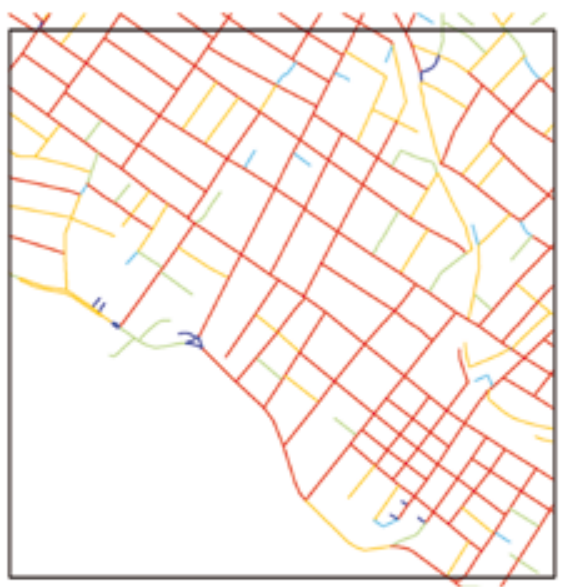

b. Erenköy

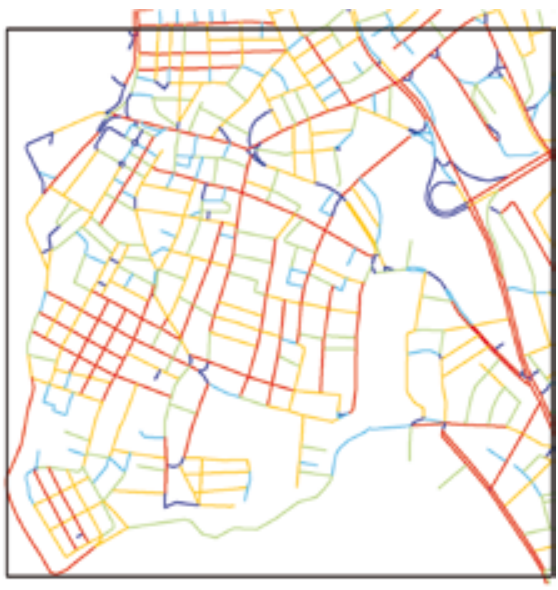

c. Moda
Figure 3. Street networks captured within the pilot areas. Streets are color-coded at the same scale according to 0 -directional reach $\left(10^{\circ}\right)$. Red colors reflect higher values, while blue colors show lower values. Thus, colors are based on the ordering of individual streets within the entire street network according to their differentiation of internal spatial structures.

\section{Pilot Areas in İstanbul}

According to 2012 census estimates İstanbul has a population of over 13 million people, and density levels are high with peak density of 68,602 people per $\mathrm{km}^{2}$-well above Manhattan's extreme (The Turkish Statistical Institute, 2013). The pilot areas were selected in particular to be reasonably representative of pedestrian-friendly environments across the city and they include both a section of the commercial center and residential neighborhood. Nişantaşı, developed at the end of the $19^{\text {th }}$ century, is one of the most vibrant commercial quarters of the city including Turkey's most expensive shopping street in terms of lease prices. Erenköy is a residential/ commercial neighborhood spanning along Bağdat Avenue, which remains the most pedestrian-oriented high street in İstanbul. Moda is prominently a residential district with low-level attached apartments inter-mixed with singular shops.

\section{Connectivity Patterns}

To assess the street connectivity patterns, the entire street network of İstanbul Metropolitan area was analyzed using the Streetmap of 2010. In this research freeways were excluded since they do not factor in pedestrian movement. Metric reach was computed for 1, 0.5 and 0.25 mile walking distance thresholds. Directional reach was computed for 0 and 2 direction changes subject to a $10^{\circ}$ angle threshold. Figure 3 shows the street networks of the pilot areas embedded within the surrounding 1-by$1 \mathrm{mile}$ grid, coded according to 0-directional reach. Even in the absence of any other design information, such as street width, a hierarchy of streets emerges based on the intrinsic relational properties of the networks.

While the pilot areas appear as variants of a gridiron, they differ significantly in terms of their street connectivity patterns. Table 1 summarizes metric and topological properties of observed street networks within 3 areas. Numerical data show that road segment-based connectivity measures discriminate well between similar morphologies of street networks. Average metric accessibility is considerably higher for Nişantaşı, and lower for Erenköy and Moda. Contrarily, average 2-directional reach $\left(10^{\circ}\right)$ is notably higher for Erenköy whereas Nişantaşı and Moda have similarly low values. Hence, these descriptive statistics with regards to street connectivity well differentiate between the spatial configurations of 3 areas with similar morphological patterns. While the selected areas display 


\begin{tabular}{llll}
\hline & $\begin{array}{l}\text { Nişantaşı } \\
\text { High metric accessibility }\end{array}$ & $\begin{array}{l}\text { Erenköy } \\
\text { High directional } \\
\text { accessibility }\end{array}$ & $\begin{array}{l}\text { Moda } \\
\text { Low street } \\
\text { connectivity }\end{array}$ \\
\hline Number of observation points (road segments) & 36 & 28 & 23 \\
\hline
\end{tabular}

\section{Characteristics of Street Connectivity at the road segment scale}

\author{
avg. Reach (1mile) \\ avg. 2 -directional reach $\left(10^{\circ}\right)$ \\ avg. segment length (m) \\ avg. block area in hectares
}

$\begin{array}{lll}74.82 & 36.42 & 31.67 \\ 4.03 & 18.34 & 3.78 \\ 102.63 & 131.41 & 71.24 \\ 1.41 & 2.43 & 0.45\end{array}$

Table 1. Characteristics of street connectivity patterns at the road segment scale for all areas.
Table 2. Characteristics of land-use patterns at the road segment scale for all areas. a similar typological street network pattern, they differ significantly in terms of their directional and metric accessibility patterns.

\section{Land-Use Patterns}

In order to address how land-use patterns at the road segment scale may contribute to culture of walking, it was incumbent to study land-use compositions within the study areas. Both the distribution of parcel-based land-uses and their numerical descriptions in terms of average densities were investigated to demonstrate the ways in which land-use patterns vary between the selected areas. Figure 4 illustrates parcel-based landuse compositions in pilot areas and Table 2 provides their numerical description at the road segment scale.

Both illustrative and numerical data reflect the differences in land-use patterns among the areas. While Nişantaşı is primarily a non-residential (mostly retail) district, Erenköy and Moda are dominated by residential uses (\%98 and \%86 of total land-use respectively). However, relying solely on land-use classification maps is likely to underestimate the prevalent trait common to all 3 areas, where ground floors of most residential uses are devoted to small retail shops. Particularly in Nişantaşı and Moda groundfloor retail contributes significantly to increased pedestrian movement densities by generating a "passing trade".

\section{Pedestrian Movement Data Collection}

Figure 5 shows the 3 areas and marks the observation sets for each area. Pedestrian counts were conducted in 2010 using the method of gate counts. In each area 20 minutes of observations were completed during working hours for each gate, distributed over 10 different time periods

\begin{tabular}{llll}
\hline & $\begin{array}{l}\text { Nişantaşı } \\
\text { Intensive non- } \\
\text { residential use }\end{array}$ & $\begin{array}{l}\text { Erenköy } \\
\text { Intensive residential } \\
\text { use }\end{array}$ & $\begin{array}{l}\text { Moda } \\
\text { Primarily residential } \\
\text { use }\end{array}$ \\
\hline Number of observation points (road segments) & 36 & 28 & 23 \\
\hline
\end{tabular}

Land-use Characteristics at the road segment scale

avg. residential $\mathrm{m}^{2} / 100 \mathrm{~m}$

avg. non-residential $\mathrm{m}^{2} / 100 \mathrm{~m}$

avg. total land-use $\mathrm{m}^{2} / 100 \mathrm{~m}$

$\begin{array}{lll}8,608.33 & 16,267.03 & 9,415.47 \\ 10,582.81 & 382.81 & 1,570.55 \\ 19,191.15 & 16,649.84 & 10,986.03\end{array}$


Figure 4. Distribution of parcel-level landuse in 3 areas.

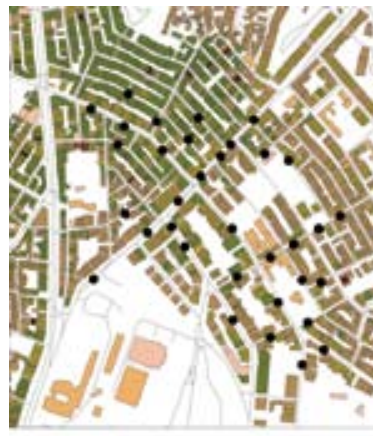

a. Nişantaşı

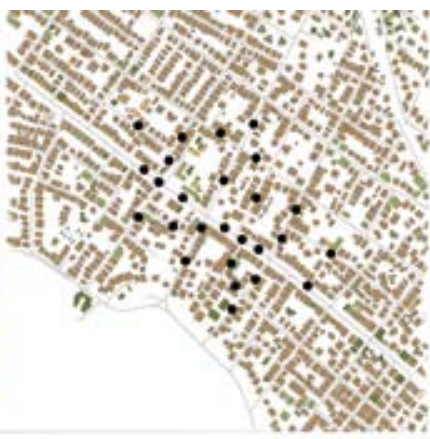

b. Erenköy

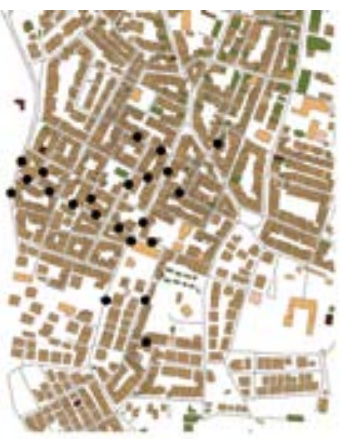

c. Moda residential $\square$ retail $=$ institutional recreational

industrial $=$ office

(between $08^{00}$ and $20^{\circ 0}$ ). A total of 84 gates were observed in the city, with 33 gates in Nişantaşı, 28 gates in Erenköy, and 23 gates in Moda. Figure 6 shows graphically the distribution of movement densities using circles of different diameters for the areas. Figure 7 provides statistical information on pedestrian densities and shows how strongly the three areas differ. The median density of moving pedestrians per 100 meters is 18.8, 5.55, and 3 for Nişantaşı, Erenköy and Moda respectively, while the corresponding means are $24,15.6$, and 6 .

\section{THE DISTRIBUTION OF PEDESTRIAN MOVEMENT DENSITIES AS A FUNCTION OF STREET CONNECTIVITY AND LAND-USE}

For the purpose of investigating the extent to which street connectivity and land-use density explain the distribution of movement per road segment the selected areas were merged into a single set and "connectivity" and "urban form" models were produced. The "connectivity" model includes connectivity measures; metric reach and 2-directional reach. The "urban form" model includes aggregate (total land-use) and disaggregate (nonresidential and residential) land-use values in addition to connectivity measures. When multivariate and bivariate regression equations were estimated for metric reach computed at $1,0.5$, and 0.25 mile ranges and directional reach for 0 and 2 direction changes separately, the highest coefficient of determination $\left(R^{2}\right)$ was obtained for metric reach computed at the 1-mile range and directional reach for 2 direction changes. Thus, linear models with metric reach computed at the 1-mile range as well as at twodirectional reach are reported in this paper.

Tables 3 to 6 summarize the results of regression models including street connectivity measures and land-use compositions. Each column shows, first, the predictability of the model with only connectivity measures, and then, in turn, the effect of adding aggregate and disaggregate land-use measures to the model. The results of multivariate models demonstrate the effect of accessibility on space use. Indeed, when all areas in İstanbul are aggregated (Table 3), metric and directional reach together explain $42 \%$ of the variation in movement (at a $99 \%$ level of confidence). The standardized coefficients for both connectivity measures are positive and statistically significant. The sign and significance of the coefficients remains consistent even after the inclusion of land-use measures. Metric reach and two-directional reach are significantly stronger than any of the land-use measures in capturing the distribution of pedestrian densities at the street level. In other words, at the local level (approximately 1 square mile, or 

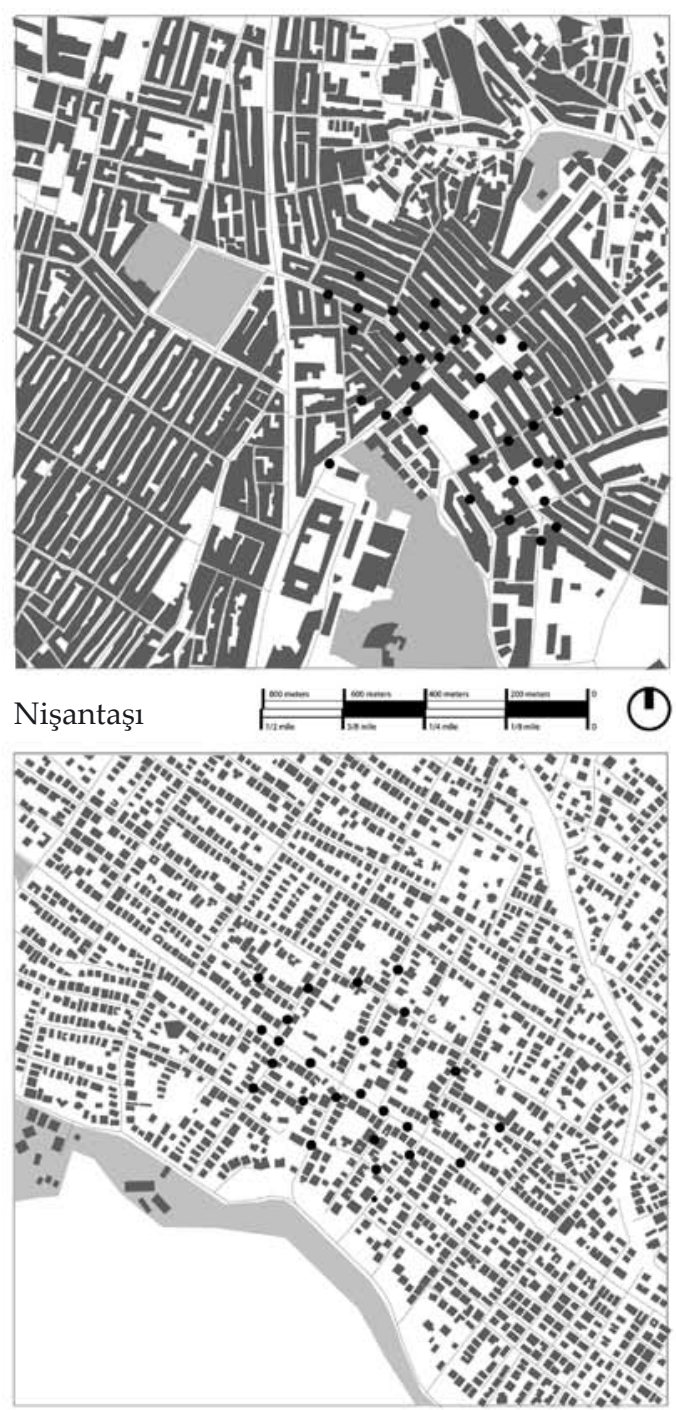

Bağdat St.
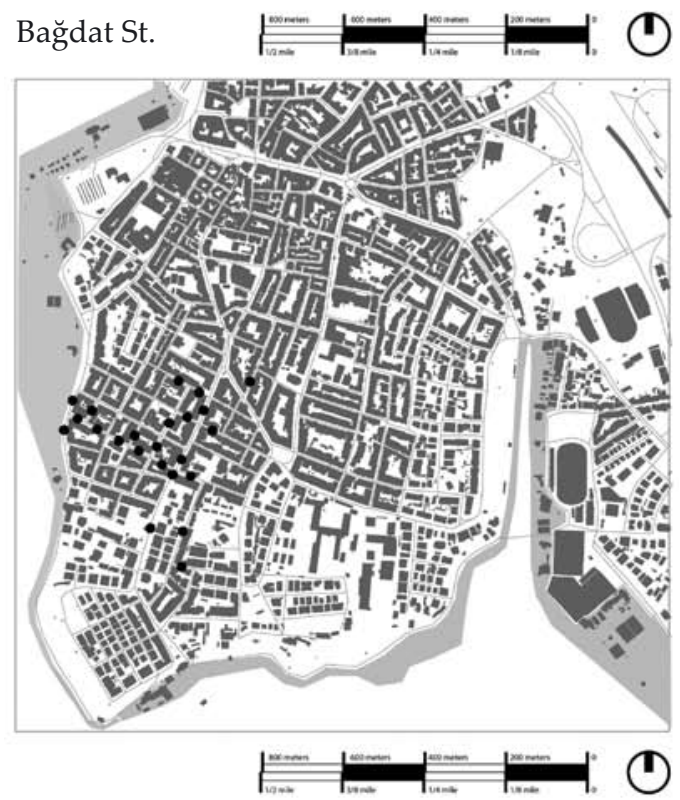

Moda
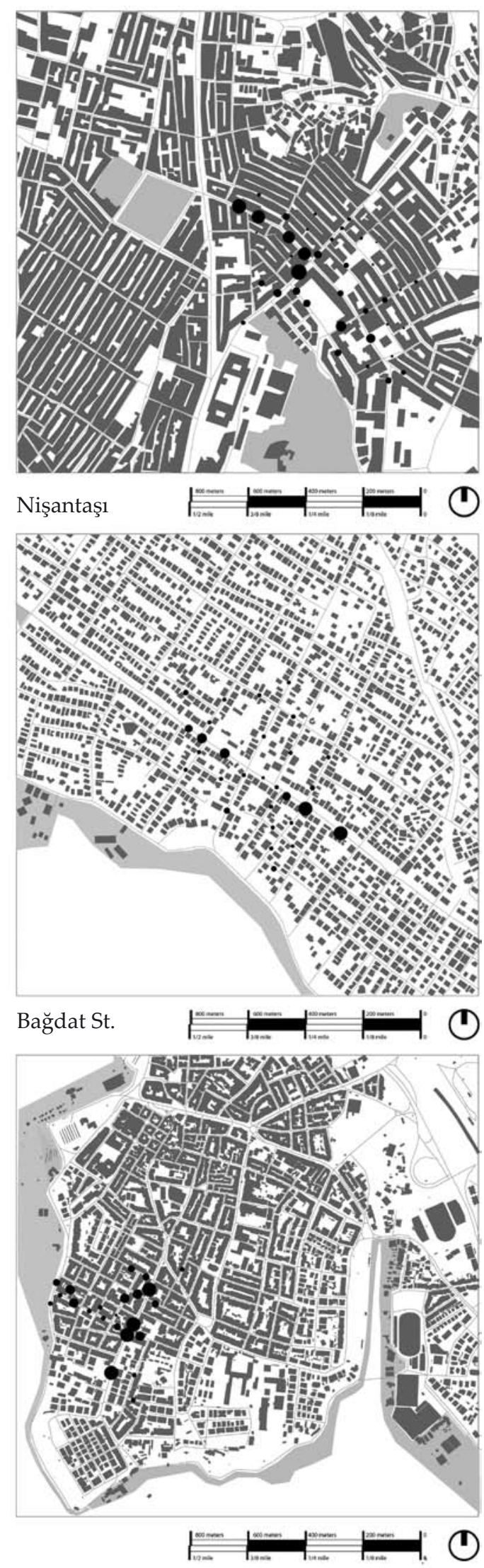

Moda 
2.6 square kilometer) the distribution of movement is primarily derived by urban layout. Consistent with theory, pedestrian movement levels are also sensitive to land-use densities. The positive coefficients of total and non-residential building square meter at the road segment scale suggest that movement levels increase with higher development densities along the road segment.

The results of multivariate regression models for individual areas designate that the configuration of urban network is the main determinant of movement at the street level (Tables 4-6). When the pilot areas are analyzed individually, the impact of street connectivity on the distribution of movement is quite consistent across areas. More significantly, directional accessibility measure (2-directional reach subject to a $10^{\circ}$ threshold angle)
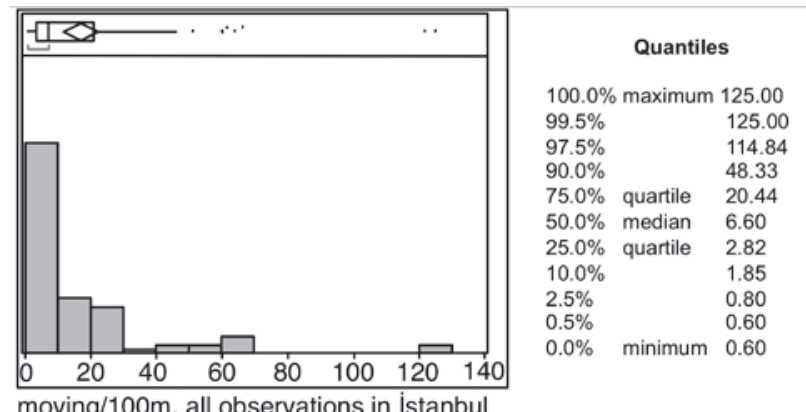

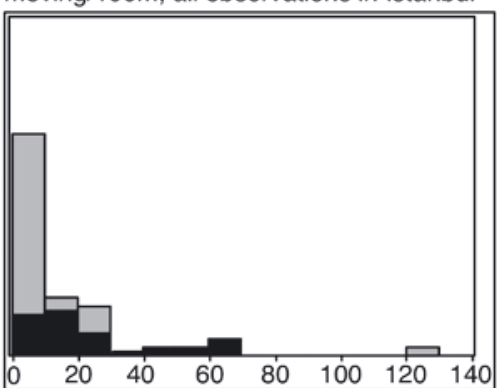

Quantiles

\begin{tabular}{|c|c|c|}
\hline 00.0 & 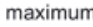 & 0.10 \\
\hline $99.5 \%$ & & 66.100 \\
\hline $97.5 \%$ & & 66.100 \\
\hline $90.0 \%$ & & 60.710 \\
\hline $75.0 \%$ & quartile & 39.225 \\
\hline $50.0 \%$ & median & 18.800 \\
\hline $25.0 \%$ & quartile & 8.800 \\
\hline $10.0 \%$ & & 3.620 \\
\hline $2.5 \%$ & & 0.800 \\
\hline & & 0.800 \\
\hline $0 \%$ & minimum & 0.800 \\
\hline
\end{tabular}

moving/100m, all observations in Nişantaşı (in black)

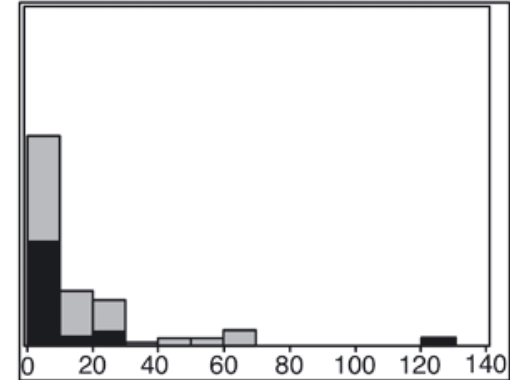

moving/100m, all observations in Erenköy (in black)

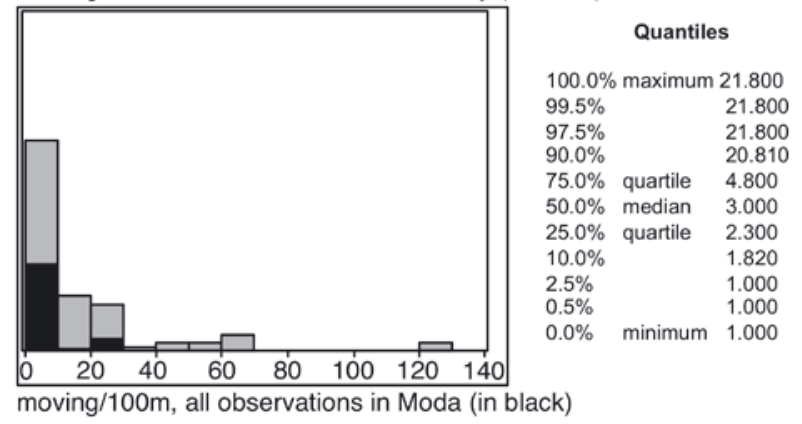

Quantiles

$\begin{array}{llc}100.0 \% & \text { maximum } & 125.00 \\ 99.5 \% & 125.00 \\ 97.5 \% & 114.84 \\ 90.0 \% & & 35.76 \\ 75.0 \% & \text { quartile } & 14.92 \\ 50.0 \% & \text { median } & 5.55 \\ 25.0 \% & \text { quartile } & 2.73 \\ 10.0 \% & & 0.89 \\ 2.5 \% & & 0.60 \\ 0.5 \% & & 0.60 \\ 0.0 \% & \text { minimum } & 0.60\end{array}$

Figure 7. Statistical Profile of Observed Pedestrian Densities in 3 pilot areas in İstanbul.

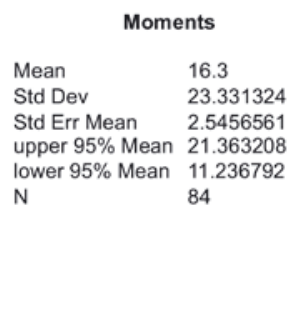

Moments

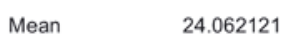

Std Dev $\quad 20.490223$

Std Err Mean $\quad 3.5668899$ upper $95 \%$ Mean 31.327638 lower $95 \%$ Mean 16.796604

N
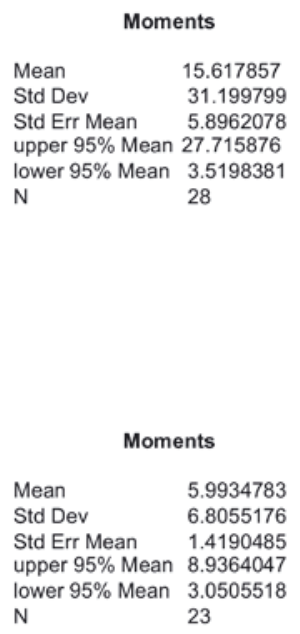

$\mathrm{N}$ 


\begin{tabular}{|c|c|c|c|c|c|c|c|c|c|}
\hline \multirow[t]{3}{*}{ Log of pedestrians $/ 100 \mathrm{~m}$} & \multicolumn{3}{|c|}{ Connectivity Model } & \multicolumn{6}{|c|}{ Urban Form Model } \\
\hline & \multicolumn{3}{|c|}{ Connectivity } & \multicolumn{3}{|c|}{ + Land-use (aggregate) } & \multicolumn{3}{|c|}{ + Land-use (disaggregate) } \\
\hline & $B$ & $t$ & $\operatorname{std} B$ & $B$ & $t$ & $\operatorname{std} B$ & $B$ & $t$ & std $B$ \\
\hline $\begin{array}{l}\text { constant } \\
\text { avg. Reach (1mile) } \\
\text { 2-Directional Reach }\left(10^{\circ}\right) \\
\text { residential } \mathrm{m}^{2} / 100 \mathrm{~m} \\
\text { non-residential } \mathrm{m}^{2} / 100 \mathrm{~m} \\
\text { total land-use } \mathrm{m}^{2} / 100 \mathrm{~m}\end{array}$ & $\begin{array}{l}0.04 \\
0.06 \\
\cdot \\
\cdot\end{array}$ & $\begin{array}{l}-1.48 \\
7.15 \\
4.87 \\
. \\
. \\
.\end{array}$ & $\begin{array}{l}\cdot \\
0.65 \\
0.44 \\
\cdot \\
\cdot \\
\end{array}$ & $\begin{array}{l}. \\
0.04 \\
0.06 \\
. \\
0.00 *\end{array}$ & $\begin{array}{l}-1.90 \\
6.60 \\
4.91 \\
. \\
- \\
2.48 *\end{array}$ & $\begin{array}{l}\cdot \\
0.60 \\
0.43 \\
\cdot \\
- \\
0.21 *\end{array}$ & $\begin{array}{l}- \\
0.03 \\
0.07 \\
0.00 \\
0.00\end{array}$ & $\begin{array}{l}-0.81 \\
4.82 \\
5.31 \\
0.60 \\
3.50 \\
-\end{array}$ & $\begin{array}{l}- \\
0.48 \\
0.46 \\
0.05 \\
0.33\end{array}$ \\
\hline $\begin{array}{l}\mathrm{N}=84 \\
\mathrm{R}^{2} \\
\mathrm{R}^{2} \text { adjusted }\end{array}$ & \multicolumn{3}{|l|}{0.42} & \multicolumn{3}{|l|}{0.46} & \multicolumn{3}{|l|}{$\begin{array}{l}0.50 \\
0.47\end{array}$} \\
\hline
\end{tabular}

Table 3. Multivariate regression for all areas considered as a single set

Note: Numbers in bold $=\mathrm{p}<0.01$; numbers with ${ }^{*}=\mathrm{p}<0.05$; numbers with $\mathrm{t}=\mathrm{p}<0.1$.
Table 4. Multivariate regression estimating the pedestrian distribution in Nişantaşı

Note: Numbers in bold $=\mathrm{p}<0.01$; numbers with * $=p<0.05$; numbers with $t=p<0.1$. appears to be the key indicator of flow rates. In all areas, the coefficients for two-directional reach are positive and statistically significant. The results indicate that the connectivity measures account for 30 to 68 percent of the variation of pedestrian movement densities. While this is a high proportion, these results also point to the possible effect of other factors, including not only the variation of land development by parcel, but also the location of parking facilities. Much movement occurs between a parking facility and a particular destination. This contributes to the fragmentary overall nature of movement. Non-residential land-use is positive and significant in all models. In other words, the number of non-residential uses located at street level attracts higher densities of pedestrian movement. In fact, in the case of Moda, non-residential land-use is stronger than any of the connectivity measures in capturing the distribution of pedestrian densities at the street level. Yet, directional accessibility measure is quite as significant, indicating that spatial configuration still preserves its effect on movement, but it is space that drives land-use at the local level.

\begin{tabular}{|c|c|c|c|c|c|c|c|c|c|}
\hline \multirow[t]{3}{*}{ Log of pedestrians/100m } & \multirow{2}{*}{\multicolumn{3}{|c|}{$\begin{array}{l}\text { Connectivity Model } \\
\text { Connectivity }\end{array}$}} & \multicolumn{6}{|c|}{ Urban Form Model } \\
\hline & & & & \multicolumn{3}{|c|}{$\begin{array}{l}\text { + Land-use } \\
\text { (aggregate) }\end{array}$} & \multicolumn{3}{|c|}{ + Land-use (disaggregate) } \\
\hline & $B$ & $t$ & std $B$ & $B$ & $t$ & std $B$ & $B$ & $t$ & $s t d B$ \\
\hline $\begin{array}{l}\text { constant } \\
\text { avg. Reach (1mile) } \\
\text { 2-Directional Reach }\left(10^{\circ}\right) \\
\text { residential } \mathrm{m}^{2} / 100 \mathrm{~m} \\
\text { non-residential m²/100m } \\
\text { total land-use } \mathrm{m}^{2} / 100 \mathrm{~m}\end{array}$ & $\begin{array}{l}0.13^{*} \\
0.26^{*} \\
\text { - } \\
\text {. }\end{array}$ & $\begin{array}{l}-2.32 \\
2.69 * \\
2.18^{*} \\
. \\
. \\
\end{array}$ & $\begin{array}{l}0.41 * \\
0.33^{*} \\
. \\
. \\
.\end{array}$ & $\begin{array}{l}0.08 \\
0.31 * \\
\text { - } \\
\text { - } \\
0.00^{*}\end{array}$ & $\begin{array}{l}-1.29 \\
1.45 \\
2.66^{*} \\
. \\
. \\
2.16^{*}\end{array}$ & $\begin{array}{l}0.24 \\
0.39 * \\
\text { - } \\
\text { - } \\
0.34 *\end{array}$ & $\begin{array}{l}0.08 \\
0.31^{*} \\
0.00 \\
0.00^{*}\end{array}$ & $\begin{array}{l}-1.27 \\
1.43 \\
2.62 * \\
0.65 \\
2.10^{*} \\
-\end{array}$ & $\begin{array}{l}0.24 \\
0.39 * \\
0.09 \\
0.33^{*}\end{array}$ \\
\hline$N=33$ & \multirow{2}{*}{\multicolumn{3}{|c|}{0.37}} & \multirow{2}{*}{\multicolumn{3}{|c|}{0.46}} & \multirow{2}{*}{\multicolumn{3}{|c|}{0.46}} \\
\hline $\mathrm{R}^{2}$ & & & & & & & & & \\
\hline $\mathrm{R}^{2}$ adjusted & \multicolumn{3}{|l|}{0.33} & \multicolumn{3}{|l|}{0.40} & \multicolumn{3}{|l|}{0.38} \\
\hline
\end{tabular}




\begin{tabular}{|c|c|c|c|c|c|c|c|c|c|}
\hline \multirow[t]{3}{*}{ Log of pedestrians/100m } & \multirow{2}{*}{\multicolumn{3}{|c|}{$\begin{array}{l}\text { Connectivity Model } \\
\text { Connectivity }\end{array}$}} & \multicolumn{6}{|c|}{ Urban Form Model } \\
\hline & & & & \multicolumn{3}{|c|}{$\begin{array}{l}\text { + Land-use } \\
\text { (aggregate) }\end{array}$} & \multicolumn{3}{|c|}{ + Land-use (disaggregate) } \\
\hline & $B$ & $t$ & $s t d B$ & $B$ & $t$ & $\operatorname{std} B$ & $B$ & $t$ & $s t d B$ \\
\hline $\begin{array}{l}\text { constant } \\
\text { avg. Reach (1mile) } \\
2 \text {-Directional Reach }\left(10^{\circ}\right) \\
\text { residential } \mathrm{m}^{2} / 100 \mathrm{~m} \\
\text { non-residential m²/100m } \\
\text { total land-use m²/100m }\end{array}$ & $\begin{array}{l}\cdot \\
-0.08^{+} \\
0.12 \\
\cdot \\
\cdot \\
\cdot\end{array}$ & $\begin{array}{l}1.66 \\
-1.93^{+} \\
7.36 \\
\cdot \\
\cdot \\
\cdot\end{array}$ & $\begin{array}{l}- \\
-0.22^{+} \\
0.85 \\
\cdot \\
\cdot \\
.\end{array}$ & $\begin{array}{l} \\
-0.07 \\
0.12 \\
\cdot \\
\\
\end{array}$ & $\begin{array}{l}1.24 \\
-1.64 \\
7.38 \\
\cdot \\
\cdot \\
0.88\end{array}$ & $\begin{array}{l}\cdot \\
-0.20 \\
0.86 \\
\cdot \\
\cdot \\
0.10\end{array}$ & $\begin{array}{l}-0.06 \\
0.10 \\
0.00 \\
0.00 * \\
\end{array}$ & $\begin{array}{l}1.24 \\
-1.58 \\
6.17 \\
1.14 \\
2.53^{*} \\
-\end{array}$ & $\begin{array}{l}- \\
-0.17 \\
0.73 \\
0.12 \\
0.29 * \\
\end{array}$ \\
\hline $\begin{array}{l}N=28 \\
R^{2} \\
R^{2} \text { adjusted }\end{array}$ & \multicolumn{3}{|l|}{0.68} & \multicolumn{3}{|l|}{$\begin{array}{l}0.69 \\
0.66\end{array}$} & \multicolumn{3}{|l|}{$\begin{array}{l}0.76 \\
0.72\end{array}$} \\
\hline
\end{tabular}

Table 5. Multivariate regression estimating the pedestrian distribution in Erenköy

Note: Numbers in bold $=\mathrm{p}<0.01$; numbers with * $=p<0.05$; numbers with $+=p<0.1$.

\begin{tabular}{|c|c|c|c|c|c|c|c|c|c|}
\hline \multirow[t]{3}{*}{ Log of pedestrians/100m } & \multirow{2}{*}{\multicolumn{3}{|c|}{$\begin{array}{l}\text { Connectivity Model } \\
\text { Connectivity }\end{array}$}} & \multicolumn{6}{|c|}{ Urban Form Model } \\
\hline & & & & \multicolumn{3}{|c|}{$\begin{array}{l}\text { + Land-use } \\
\text { (aggregate) }\end{array}$} & \multicolumn{3}{|c|}{ + Land-use (disaggregate) } \\
\hline & $B$ & $t$ & std $B$ & $B$ & $t$ & std B & $B$ & $t$ & $s t d B$ \\
\hline $\begin{array}{l}\text { constant } \\
\text { reach (1mile) } \\
\text { 2-Directional Reach }\left(10^{\circ}\right) \\
\text { residential m²/100m } \\
\text { non-residential m²/100m } \\
\text { total land-use m²/100m }\end{array}$ & $\begin{array}{l}. \\
0.03 \\
0.34^{*} \\
. \\
. \\
.\end{array}$ & $\begin{array}{l}-0.56 \\
0.62 \\
2.73^{*} \\
. \\
- \\
.\end{array}$ & $\begin{array}{l}\cdot \\
0.13 \\
0.52 * \\
. \\
. \\
.\end{array}$ & $\begin{array}{l}. \\
0.02 \\
0.25^{*} \\
. \\
0.00\end{array}$ & $\begin{array}{l}-0.59 \\
0.43 \\
2.25^{*} \\
\cdot \\
- \\
2.86\end{array}$ & $\begin{array}{l}\cdot \\
0.07 \\
0.38 * \\
. \\
. \\
0.48\end{array}$ & $\begin{array}{l}- \\
0.02 \\
0.23^{*} \\
0.00 \\
0.00^{*}\end{array}$ & $\begin{array}{l}-0.50 \\
0.53 \\
2.13^{*} \\
1.12 \\
2.57^{*}\end{array}$ & $\begin{array}{l}. \\
0.09 \\
0.36^{*} \\
0.19 \\
0.44^{*}\end{array}$ \\
\hline $\begin{array}{l}\mathrm{N}=23 \\
\mathrm{R}^{2} \\
\mathrm{R}^{2} \text { adjusted }\end{array}$ & \multicolumn{3}{|l|}{$0.30 *$} & \multicolumn{3}{|l|}{0.51} & \multicolumn{3}{|l|}{0.54} \\
\hline
\end{tabular}

Table 6. Multivariate regression estimating the pedestrian distribution in Moda

Note: Numbers in bold $=\mathrm{p}<0.01$; numbers with * $=p<0.05$; numbers with $+=p<0.1$.
Variables which are not statistically significant at the 0.01 level in the multivariate regression model for all areas considered as a single set were eliminated to arrive at a "reduced" model (Table 7). The model shows that distribution of pedestrian movement is most sensitive to density and alignment of street network. Metric reach and two-directional reach appear to be equally significant predictors of movement flows. In fact, the model suggests that connectivity measures impact movement more than nonresidential land-use density per road segment. 
Table 7. Reduced model for all areas considered as a single set

Note: Numbers in bold $=\mathrm{p}<0.01$; numbers with ${ }^{*}=p<0.05 ;$ numbers with $\dagger=p<0.1$.

\begin{tabular}{|l|l|l|l|}
\hline log of pedestrians/100m & \multicolumn{3}{|l|}{ Reduced Model } \\
\hline & $B$ & $t$ & std B \\
\hline constant & - & -0.64 & - \\
Reach (1mile) & $\mathbf{0 . 0 3}$ & $\mathbf{4 . 8 0}$ & $\mathbf{0 . 4 7}$ \\
2-Directional Reach $\left(10^{\circ}\right)$ & 0.07 & 5.41 & $\mathbf{0 . 4 6}$ \\
non-residential $\mathrm{m}^{2} / 100 \mathrm{~m}$ & $\mathbf{0 . 0 0}$ & $\mathbf{3 . 5 1}$ & $\mathbf{0 . 3 3}$ \\
\hline $\mathrm{N}=84$ & \multicolumn{3}{|l}{} \\
$\mathrm{R}^{2}$ & 0.49 \\
$\mathrm{R}^{2}$ adjusted & 0.47 & \multicolumn{3}{|l}{} \\
\hline
\end{tabular}

\section{DISCUSSION}

This work is still in progress and conclusions are, at this stage, tentative. Overall, the analyses presented here confirm the hypothesis that both land-use compositions and configuration of street network have significant impact on the distribution of pedestrian movement within the urban fabric, yet the connectivity measures capture the distribution of movement at the road segment level over and above land-uses. The findings of this research lend specific support for three main conclusions that have significant implications for urban planning and urban design decisions aimed to reduce automobile dependence and induce non-auto commuting.

First, the results of this study emphasize the importance of including measures of street connectivity in urban design and planning studies. It is shown that the configuration of street network is the fundamental correlate of walking at the street level. In other words, street networks with denser and more direct connections are associated with higher levels of movement rates. The spatial structure of street network does not work independently of land-use. On the contrary, based on the standardized coefficients estimated in regression models, street network and nonresidential development density have comparably high positive impacts on flow rates. More work that takes into account socio-demographic factors (such as population and employment densities) is needed in order to shed more light on the interplay between street layout, pedestrian distribution, and land-use patterns.

Second, these preliminary results, not exhaustive but noteworthy, suggest that the new connectivity measures of GIS-based representation can provide alternative means to quantify urban properties and capture a subtler relationship between movement patterns and urban systems. It is shown that road segment-based connectivity measures discriminate well between similar morphologies of street networks as well as between road segments within the same urban area. Hence, findings of this study are relevant for planners and designers. They capture both the interaction between street connectivity and land-uses, and the relational properties of urban network. This indicates that further research which takes into account connectivity and land-use measures at the street scale might help elucidate the different attributes of the urban network in explaining the distribution of pedestrian movement.

Third, this analysis has consequences for at least some kinds of local urban economy: in İstanbul retail still relies on the "passing trade" because of the finer grain not only of the street network but also the size of businesses. The prevalent trait in İstanbul, where ground floors of most 
residential uses function as small retail/commercial shops spread within the entire neighborhood, contributes to the higher rates of pedestrian flow encouraged by the higher street connectivity in terms of density. Here the term density refers to the amount of street which is available within a given metric range. Accordingly the new measures express the density of street connectivity directly. As the data base and analyses expand, it might be possible to throw more light on the interplay between measures of the density of connections and land-use compositions as determinants of pedestrian flows.

\section{REFERENCES}

AULTMAN-HALL, L., ROORDA, M., BAETZ, B. (1997) Using GIS for Evaluation of Neighborhood Pedestrian Accessibility, Journal of Urban Planning and Development (123:1) 10-17.

BAILENSON, J.N., SHUM, M.S., UTTAL, D.H. (2000) The initial segment strategy: A heuristic for route selection, Memory \& Cognition (28) 306318.

CERVERO, R. (1988) Land-use Mixing and Suburban Mobility, Transportation Quarterly (42:3) 429-446.

CERVERO, R. (1989) Jobs-Housing Balancing and Regional Mobility, Journal of the American Planning Association (55) 136-150.

CERVERO, R. (1996) Mixed land-uses and commuting: evidence from the American housing survey, Transportation Research (30:5) 361-377.

CERVERO, R., KOCKELMAN, K. (1997) Travel Demand and the 3Ds: Density, Diversity, and Design, Transportation Research Part D: Transport and Environment (2:3) 199-219.

CRANE, R., CREPEAU, R. (1998) Does neighborhood design influence travel?: A behavioral analysis of travel diary and GIS data, Transportation Research Part D: Transport and Environment (3) 225-238.

CROWE, D., AVERBECK, B., CHAFEE, M., ANDERSON, J., GEORGOPOULOS, A. (2000) Mental maze solving, Journal of Cognitive Neuroscience (12) 813-827.

DUNPHY, R., FISHER, K. (1996) Transportation, Congestion, and Density: New Insights, Transportation Research Record (1552) 89-96.

EWING, R., HALIYUR, P., PAGE, G. (1994) Getting around a traditional city, a suburban planned unit development, and everything in between, Transportation Research Record (1466) 53-62.

EWING, R., CERVERO, R. (2001) Travel and the built environment: a synthesis, Transportation Research Record: Journal of the Transportation Research Board (1780) 87-114.

FRANK, L.D., PIVO, G. (1994) Impacts of Mixed Use and Density on Utilization of Three Modes of Travel: Single-Occupant Vehicle, Transit, and Walking, Transportation Research Record (1466) 44-52.

GEHL, J., KAEFER, J.L., REIGSTAD, S. (2006) Close encounters with buildings, Urban Design International (11) 29-47.

GUILIANO, G. (1991) Is Jobs-Housing a Transportation Issue? Achieving a JobsHousing Balance: Land-use Planning for Regional Growth, The Lincoln Institute, Cambridge. 
HANDY, S.L., (1996) Urban Form and Pedestrian Choices: Study of Austin Neighborhoods, Transportation Research Record (1552) 135-144.

HANDY, S., PATERSON, R., BUTLER, K. (2003) Planning for street connectivity: getting from here to there, APA, Chicago.

HANDY, S., CAO, X., MOKHTARIAN, P. (2005) Correlation or causality between the built environment and travel behavior? Evidence from Northern California, Transportation Research Part D: Transport and Environment (10) 427-444.

HESS, P.M. (1997) Measures of Connectivity, Places (11:2) 59-65.

HESS, P., MOUDON, A., SNYDER, M., STANILOV, K. (1999) Site design and pedestrian travel, Transportation Research Record: Journal of the Transportation Research Board (1674) 9-19.

HILLIER, B., HANSON, J., PEPONIS, J., HUDSON, J., BURDETT, R. (1983) Space syntax: a different urban perspective, Architect's Journal (178:48) 47-63.

HILLIER, B., HANSON, J. (1984) The Social Logic of Space, Cambridge University Press, Cambridge.

HILLIER, B., BURDETT, R., PEPONIS, J. AND PENN, A. (1987) Creating Life: Or, Does Architecture Determine Anything?, Architecture and Behaviour, (3) 233-250.

HILLIER, B., PENN, A., HANSON, J., GRAJEWSKI, T., XU, J. (1993) Natural Movement or, configuration and attraction in urban pedestrian movement, Environment and Planning (B): Planning and Design, (20:1) 29-66.

HILLIER, B. (1996) Space is the Machine, Cambridge University Press, Cambridge.

HILLIER, B. (1999a) Centrality as Process: accounting for attraction inequalities in deformed grids, Urban Design International (4) 107-127.

HILLIER, B. (1999b) The hidden geometry of deformed grids: or, why space syntax works, when it looks as though it shouldn't, Environment and Planning (B): Planning and Design (26) 169-191.

HILLIER, B., IID A, S. (2005) Network effects and psychological effects: a theory of urban movement, proceedings from the $5^{\text {th }}$ International Symposium on Space Syntax, Techne Press, A.V. Ness, Delft, 553-564.

HOLTZCLAW, J. (1994) Using residential patterns and transit to decrease auto dependence and costs, Natural Resources Defense Council, San Francisco.

KRIZEK, K.J. (2003) Residential Relocation and Changes in Urban Travel, Journal of the American Planning Association (69:3) 265-281.

LEE, C., MOUDON, A.V. (2006) The 3Ds + R: Quantifying land use and urban form correlates of walking, Transportation Research Part $D$ (11:3) 204-215.

MONTELLO, D. (1991) Spatial Orientation and the Angularity of Urban Routes. A Field Study, Environment and Behavior (23) 47-69.

MOUDON, A.V., LEE, C., CHEADLE, A.D., GARVIN, C., JOHNSON, D., SCHMID, T.L., WEATHERS, R.D. AND LIN, L. (2006) Operational 
Definitions of Walkable Neighborhood: Theoretical and Empirical Insights, Journal of Physical Activity and Health (3:1) S99-S117.

NEWMAN, P., KENWORTHY, J. (1989) Gasoline Consumption and Cities, JAPA (55:1) 24-37.

PENN, A., HILLIER, B., BANISTER, D., XU, J. (1998) Configurational modelling of urban movement networks, Environment and Planning (B): Planning and Design (25) 59-84.

PEPONIS, J. (1989) Space, culture and urban design in late modernism and after, Ekistics (56) 93-108.

PEPONIS, J., HADJINIKOLAOU, E., LIVIERATOS, C., FATOUROS, D.A. (1989) The Spatial core of urban culture, Ekistics (56:334-335) 43-55.

PEPONIS, J., ROSS, C., RASHID, M., KIM, S.H., VARELA, G., SENTOSA, L. (1996) Regularity and change in urban space: A syntactic analysis of movement and co-presence in Atlanta, Ekistics (63:376) 4-16.

PEPONIS, J., ROSS, C., RASHID, M. (1997) The Structure of Urban Space, Movement and Co-presence: The Case of Atlanta, Geoforum (28:3-4) 341-358.

PEPONIS, J., BAFNA, S., ZHANG, Z.Y. (2008) The connectivity of streets: reach and directional distance, Environment and Planning B-Planning and Design (35) 881-901.

PUSHKAREV, B., ZUPAN, J. (1977) Public Transportation and Land-use Policy, Indiana University Press, Bloomington, IN.

RANDALL, T.A., BAETZ, B.W. (2001) Evaluating Pedestrian Connectivity For Suburban Sustainability, Journal of Urban Planning and Development (127:1) 1-15.

RODRIGUEZ, D., KHATTAK, A., EVENSON, K. (2006) Can New Urbanism Encourage Pyhsical Activity?: Comparing a New Urbanist Neighborhood with Conventional Suburbs, Journal of the American Planning Association (72) 43-54.

SADALLA, E., MAGEL, S. (1980) The perception of traversed distance, Environment and Behavior (12) 183-193.

SADALLA, E.K., MONTELLO, D.R. (1989) Remembering Changes in Direction, Environment and Behavior (21) 346-363.

SIKSNA, A. (1997) The evolution of block size and form in North American and Australian city centers, Urban Morphology (1:1) 19-34.

SOUTHWORTH, M., OWENS, P.M. (1993) The Evolving Metropolis Studies of Community, Neighborhood, and Street Form at the Urban Edge, Journal of the American Planning Association (59:3) 271-287.

The Turkish Statistical Institute. (2013). The Results of Address Based Population Registration System, 2012. [http://www.turkstat.gov.tr/ PreHaberBultenleri.do?id=13425] Accessed (28.01.2013). 
Alınd1: 04.07.2012; Son Metin: 03.12.2012

Anahtar Sözcükler: Yol ağı bağlantılığı; yaya hareketi; kentsel hareket şebekesi; arazi kullanımı; İstanbul.

\section{KENTLERDEKİ YAYA HAREKETININ YOL AĞI VE ARAZİ- KULLANIM ÖZELLIKKLERİ DOĞRULTUSUNDA İNCELENMESİ: İSTANBUL ÖRNEĞİ}

Kentsel biçimin yaya hareketi üzerine olan etkilerini inceleyen araştırmalar yapılaşmış çevreyi öznel değerlerle ölçümlemekte, fiziksel çevrenin nesnel değerlendirmesinde yetersiz kalmaktadır. Bunun başlıca nedeni ulaşım ve kent plancılarının yaygın olarak kullandıkları kentsel biçim ölçütlerinin, kaldırım ölçüleri ve tasarımı, bina cephelerinin kalitesi ya da mevcut çevresel konfor düzeyi gibi çoğunlukla fiziksel çevrenin yerel niteliği ile sınırlı değişkenleri içermesidir. Ancak çevresel etmenler gerçekte tüm bir bölgenin -mahalle, semt veya şehir- özelliği ya da niteliği ile doğrudan ilişkilidir. Mevcut kent dokusunun mekansal ve yapısal özelliklerini göz ardı eden istatistiksel hesaplamalar yanlış sonuçlar doğurmaktadır. Ayrıca, bu tür çevresel etmenlerin kullanıldığı çalışmalardan çıkan bulguların yürünebilir kentlerin oluşturulması için gerekli tasarım ilkelerine dönüştürülmesi de güçtür.

$\mathrm{Bu}$ çalışma, yerel ve algısal etmenlerin yanısıra fiziksel çevrenin mekansal ve yapısal niteliklerinin de yürüme davranışını şekillendirmede önemli rol oynadığı önerimine dayanmaktadır. Bu çalışmanın amacı kentsel yol ağı düzenlenişi, arazi kullanım şekilleri ve yaya dolaşım yoğunlukları arasındaki ilişkiyi ortaya koymaktır. Bu amaç doğrultusunda İstanbul'da üç farklı alan belirlenerek analiz edilerek yaya dağılımını açılamaya yönelik istatistiksel modeller geliştirilmiştir. Modellerde parsel ölçeğindeki arazi kullanım değerlerinin yanı sıra kentsel yol ağını ayrıntılı ve nesnel olarak ölçebilen yol-parçası ölçekli (road segment-based) bağlantılılık (street connectivity) ölçütleri de kullanılmıştır. Bu ölçütlerden Metrik Erişim, belirli bir yürüme çapı içinde erişilebilen yol ağı uzunluğunu ölçer. Açısal Erişim ise belirli sayıdaki açısal değişim dahilinde erişilebilen yol ağı uzunluğunu ölçer.

Modellerin sonuçları, hem arazi kullanımının hem de yol ağı düzeninin kentsel alandaki yaya yoğunluklarının dağılımını önemli ölçüde etkilediğini göstermektedir. Çalışmanın çıktıları bir kaç açıdan önem taşımaktadır. Hem yol ağı tasarımını hem de yoğunluğunu göz önüne alan bağlantılılık ölçütlerine odaklanan bu çalışma, kentsel yol ağının yaya hareketi üzerine olan etkisini ölçmeye yönelik mevcut çalışmaları bütünlemektedir. Ayrıca geliştirilen modeller, arazi kullanım örüntüsünün yaya hareketi üzerindeki etkilerini açığa çıkarmaktadırlar. Sonuçlar, belirli bir alandaki ortalama yaya hareketi yoğunluğunun belirlenmesinde arazi kullanımının önemli bir rol oynadığını, buna karşın mekansal düzenin bir alandaki yaya hareketinin dağılımını belirlemede daha önemli bir etken olduğunu ortaya koymaktadır. Kentsel tasarım ve kentsel imar planlarının uzun vadeli etkilerini ölçmekte yararlı olacak bu modeller sürdürülebilir kentleşme için büyük önem taşımaktadır.

AYŞE ÖZBİL; B. Arch, M.Arch, Ph.D.

Received B.Arch (2000) from Yild1z Technical University, M.Arch (2002) from METU and Ph.D. (2010) in Architecture from Georgia Institute of Technology. Is currently an assistant professor at Okan University where she teaches design in architecture and urban design and morphology. ayse.ozbil@okan.edu.tr 
